\title{
1 Soil Organic Carbon is Increased in Mixed-species Plantations of Eucalyptus
}

2 and Nitrogen-fixing Acacia

3 Short title: Soil carbon under mixed-species plantations

4

5

D. I. Forrester ${ }^{1,2,3, *}$, A. Pares ${ }^{2,5}$, C. O’Hara ${ }^{2,4}$, P. K. Khanna ${ }^{1}$ and J. Bauhus ${ }^{1,2}$

6

$7 \quad{ }^{1}$ Institute of Silviculture, Freiburg University, Tennenbacherstr. 4, 79106 Freiburg, Germany

$8 \quad 2$ authors formerly at Fenner School of Environment and Society, The Australian National

9 University, Canberra, Australian Capital Territory 0200, Australia

$10{ }^{3}$ Department of Forest and Ecosystem Science, The University of Melbourne, 500 Yarra

11 Boulevard, Richmond, Victoria 3121, Australia

$12{ }^{5}$ present address: National Parks and Wildlife Service of New South Wales,

$13{ }^{4}$ present address: Ministry of Defence, Russell, Australian Capital Territory 2600, Australia

14 RECEIVED 6 JUNE 2012; ACCEPTED 23 AUGUST 2012

$15 *$ Corresponding author (davidif@ unimelb.edu.au)

16 Author contributions:

17 PK designed the long-term experiment and JB and PK conceived the study. DF, CO, AP

18 performed the research. CO developed the fractionation methodology. DF analyzed the data and

19 DF and JB wrote the paper. 


\section{ABSTRACT}

24 Soil organic carbon (soil C) sequestration in forests is often higher under nitrogen $\left(\mathrm{N}_{2}\right)$-fixing

25 than under non- $\mathrm{N}_{2}$-fixing tree species. Here, we examined whether soil $\mathrm{C}$ could be increased

26 using mixed-species plantations compared to monocultures, which are less productive above-

27 ground than mixtures. In addition, we compared soil $\mathrm{C}$ sequestration under $\mathrm{N}_{2}$-fixing trees with

28 non- $\mathrm{N}_{2}$-fixing trees that received $\mathrm{N}$ fertilizer. Monocultures of Eucalyptus globulus (E) and the

$29 \mathrm{~N}_{2}$-fixing Acacia mearnsii (A) and mixtures of these species were planted in a replacement

30 series: $100 \% \mathrm{E}, 75 \% \mathrm{E}+25 \% \mathrm{~A}, 50 \% \mathrm{E}+50 \% \mathrm{~A}, 25 \% \mathrm{E}+75 \% \mathrm{~A}$, and $100 \% \mathrm{~A}$. Soil samples were

31 also collected from fertilized monoculture treatments (100\%EFer) of E. globulus $\left(250 \mathrm{~kg} \mathrm{~N} \mathrm{ha}^{-1}\right)$.

32 Total organic $\mathrm{C}, \mathrm{N}$ and phosphorus $(\mathrm{P})$ were determined at age 8 years at two soil depths $(0-10$

$33 \mathrm{~cm}$ and $10-30 \mathrm{~cm})$ and three density fractions of soil organic matter (SOM) were quantified for 0-

$345 \mathrm{~cm}$ depth. Soil C was highest in the $50 \% \mathrm{E}+50 \% \mathrm{~A}$ mixed stand and was highly correlated with

35 aboveground biomass, not to the percentage of $A$. mearnsii in mixtures. This was largely due to

36 soil $\mathrm{C}$ at $10-30 \mathrm{~cm}$ because there were no treatment effects on soil $\mathrm{C}$ at $0-10 \mathrm{~cm}$. All density

37 fractions of SOM at $0-5 \mathrm{~cm}$ increased with the percentage of A. mearnsii. In E. globulus

38 monocultures, $\mathrm{N}$ fertilization did not increase soil $\mathrm{C}$ when compared with unfertilized stands.

39 These results indicate that the inclusion of $\mathrm{N}_{2}$-fixing trees into eucalypt plantations may increase

$40 \quad$ soil $\mathrm{C}$ stocks through increased productivity.

42 Keywords: soil carbon sequestration; organic matter fractionation; decomposition; nitrogen-

43 fixation 
47 Forest management is increasingly focusing on maintaining or augmenting soil organic carbon

48 (soil C) levels. The organic carbon in forests soils is not only important to soil fertility and

49 nutrient cycling, but also as a major storage pool in the global C cycle (Canadell and Raupach

50 2008; Schmidt and others 2011; Dungait and others 2012). For these reasons, afforestation of

51 formerly deforested land is regarded as a means to sequester atmospheric C (Canadell and

52 Raupach 2008). Soil C sequestration varies strongly with tree species (Binkley and Giardina

53 1998) and it may be of particular interest to use tree species for afforestation that increase soil C.

54 Several studies in temperate and tropical regions have shown that given similar aboveground

55 productivities, soil $\mathrm{C}$ sequestration in forest soils is greater under $\mathrm{N}_{2}$-fixing than under non- $\mathrm{N}_{2-}$

56 fixing species (Kaye and others 2000; Johnson and Curtis 2001; Resh and others 2002; Binkley

57 2005; Jeddi and others 2009; Wang and others 2010).

59 The mechanisms behind differences in soil $\mathrm{C}$ under $\mathrm{N}_{2}$-fixing species are not well established and

60 are likely to be the net effect of three processes (Figure 1; Binkley 2005). Soil C could increase

61 by (1) increasing detritus inputs, (2) decreasing rates of decomposition of the recent detrital C

62 pool or the stabilized/old $\mathrm{C}$ pool, or (3) by increasing the rate at which the recent detritial $\mathrm{C}$ is

63 incorporated into the pool of stabilized or slowly turning over soil C. The effects of $\mathrm{N}_{2}$-fixing

64 species on changes in soil C appear to vary from those of fertilizer N (Gregorich and others

65 2001), although few comparisons are available for the same sites. For example, soil C increased

66 under F. moluccana when compared with E. saligna plantations in Hawaii (Kaye and others

67 2000; Resh and others 2002), but on nearby sites, large applications of N fertilizer had no

68 significant effect on soil C compared with unfertilized E. saligna plantations (Binkley and others 
2004). This suggests that nitrogen per se may not have the main influence on soil C dynamics,

70 and instead changes in soil biology may influence decomposition (Binkley and others 2004;

71 Binkley 2005).

73 The potential to increase soil $\mathrm{C}$ with $\mathrm{N}_{2}$-fixing species could be further enhanced by increasing

74 stand productivity and hence the production of litter through mixing with non- $\mathrm{N}_{2}$-fixing tree

75 species. Many studies have found that mixing Eucalyptus species with $\mathrm{N}_{2}$-fixing species can

76 significantly increase productivity (Forrester and others 2006b), however, few studies have

77 compared soil $\mathrm{C}$ in mixtures and monocultures. In these cases, increasing soil $\mathrm{C}$ with increasing

78 proportions of the $\mathrm{N}_{2}$-fixing species (Vogel and Gower 1998; Kaye and others 2000; Mao and

79 others 2010) or no significant changes have been reported (Wang and others 2009; Voigtlaender

80 and others 2011). Both studies that included eucalypts (Kaye and others 2000; Voigtlaender and

81 others 2011) were in the tropics, where changes in soil C following afforestation are often greater

82 than those in temperate regions (Paul and others 2002).

84 Soil organic matter (SOM) is not homogeneous; it is a continuum from freshly incorporated plant

85 debris to highly decomposed OM. Different physical fractions of particulate organic matter

86 (POM) may provide additional information about $\mathrm{OM}$ functions and associated nutrient cycling

87 processes, particularly when a given change in $\mathrm{N}$ availability has opposing influences on different

88 POM fractions (Post and Kwon 2000; Neff and others 2002; Russell and others 2004). In

89 addition, rates of OM decomposition can correlate with its chemistry, such as $\mathrm{N}$ concentration

90 and the fraction of OM that is not hydrolyzed by strong acid treatments (Taylor and others 1991).

91 Therefore we analyzed in addition to total quantities of $\mathrm{C}$ and $\mathrm{OM}$, the acid hydrolyzable fraction 
92 in different physical fractions of particulate organic matter and the concentrations of $\mathrm{N}$ and $\mathrm{P}$ in

93 these physical fractions.

94

95 This study examined soil C in mixtures and monocultures of Eucalyptus globulus and Acacia

96 mearnsii in temperate, south-eastern Australia. In this experiment the aboveground biomass of

97 1:1 mixtures was $30 \%$ or $86 \%$ higher than A. mearnsii or E. globulus monocultures, respectively, 98 at age 10.7 years. We aimed to determine:

99 1. Whether the soil $\mathrm{C}$ increased with increasing proportions of $A$. mearnsii, as suggested by 100 studies comparing monocultures of $\mathrm{N}_{2}$-fixing and non- $\mathrm{N}_{2}$-fixing species, or whether soil

101 C was highest in mixtures, consistent with aboveground biomass and litter production,

102 2. Whether early rates of OM decomposition increased, whereas later stages decreased, with

103 increasing proportions of $A$. mearnsii by examining the mass of different density

104 fractions of soil organic matter and their $\mathrm{N}$ concentrations, and

105 3. Whether the addition of $250 \mathrm{~kg} \mathrm{ha}^{-1}$ of $\mathrm{N}$ fertilizer to E. globulus monocultures had 106 similar effects on soil $\mathrm{C}$ to addition of $\mathrm{N}_{2}$-fixing species in mixtures.

108 MATERIALS AND METHODS

109

110 Experimental design and site characteristics

111 The experiment was located $5 \mathrm{~km}$ southeast of Cann River in East Gippsland, Victoria, Australia $112\left(37^{\circ} 35^{\prime} \mathrm{S}, 149^{\circ} 10^{\prime} \mathrm{E}\right)$. Prior to trial establishment the site vegetation was a dry sclerophyll forest 113 dominated by Eucalyptus sieberi (L. Johnson) (Costermans 1983). The site is about 100-120 m 114 a.s.1.. Soils are Mottled, Dystrophic, Brown Kurosols (Dy5.21) or Mottled, Mesotrophic, Brown 
115 Dermosols (Gn4.31) (Stace and others 1968; Isbell 1998) and have sandy loam A horizons, sandy

116 clay loam B1 and B21 horizons and a light to medium clay B22 horizon. The $\mathrm{pH}\left(\mathrm{H}_{2} \mathrm{O}\right)$ ranges

117 from 4.6 to 5.7. The average annual rainfall at Cann River is $1009 \mathrm{~mm}$ and is evenly distributed

118 throughout the year. The mean maximum temperature is $26^{\circ} \mathrm{C}$ in January and the mean minimum

119 temperature is $6.2^{\circ} \mathrm{C}$ in July.

120

121 Eucalyptus globulus ssp. pseudoglobulus (Naudin ex Maiden) Kirkpatr. and Acacia mearnsii De

122 Wild. were planted in a replacement series of monocultures (100E and 100A) and mixtures

123 containing 75,50 or $25 \%$ E. globulus (75E:25A, 50E:50A and 25E:75A). Plots were arranged in

124 a randomized block design with four replicate blocks. Trees were planted at a spacing of $3.33 \mathrm{~m}$

125 (1010 trees $\mathrm{ha}^{-1}$ ) in plots that were $23 \mathrm{~m} 28 \mathrm{~m}$, including a surrounding row of buffer trees. In

126 the mixed-species plots trees were mixed within rows, resulting in a checkerboard arrangement.

127 E. globulus seedlings were planted in early July 1992 and A. mearnsii in early October 1992. The

128 stands were fertilized with $25 \mathrm{~kg} \mathrm{P} \mathrm{ha}^{-1}$ in the form of superphosphate, which was applied on the

129 surface of planting mounds, about $25 \mathrm{~cm}$ from the tree, three months after establishment.

130

131 To compare the effects of symbiotically fixed $\mathrm{N}$ with those of fertilizer $\mathrm{N}$ on soil $\mathrm{C}$, additional

132 plots were established in monospecific stands of E. globulus ssp. pseudoglobulus that received $\mathrm{N}$

133 fertilizer (E100Fer). These stands were located in an experiment that was planted at the same

134 time, received the same site preparation treatments and was located on the same site, adjacent to

135 the species replacement series. This treatment received N, P, and $\mathrm{K}$ at cumulative rates of 250 ,

136160 , and $170 \mathrm{~kg} \mathrm{ha}^{-1}$, respectively, by 14 months. Samples were also collected from the 
137 surrounding native forest, which resembles ecosystem conditions prior to clearing and plantation 138 establishment.

\section{Total soil C, nitrogen and phosphorous at $\mathbf{0 - 3 0} \mathrm{cm}$ depth}

141 Soil sampling took into account the distinct micro-topography created by site preparation, which

142 involved ripping to $60 \mathrm{~cm}$ and mounding of soils over rip lines, after the native vegetation was

143 cleared and the logs had been removed or burned in windrows. Plots were divided into (i)

144 mounds on which the trees were planted, (ii) trenches that were created by plough discs to build

145 the mounds and (iii) flat uncultivated areas between the trenches. Line-transects running

146 perpendicular to the mounds were used to show that the stand area consisted of $21 \%, 41 \%$ and

$14738 \%$ trench, mound and flat areas, respectively. These data were used when converting soil and 148 litter $\mathrm{C}$ concentrations to per ha values.

150 Soil samples were collected in November 2000 at about age 8.1 years. Eight pairs of soil cores

151 (7.5 cm diameter) were collected from each microsite in each treatment. Each pair was combined 152 into a single sample and no surface litter was included. These cores were divided into $0-10 \mathrm{~cm}$ 153 and 10-30 cm depths. In monocultures and 50E:50A, soil cores were collected at mid-points 154 between trees. In 75E:25A and 25E:75A, soil cores on the flats were also collected at the center 155 of four trees, but on the mounds and in the trenches the soil cores were collected about $80-90 \mathrm{~cm}$ 156 from the more abundant species to be more representative of the plot conditions. Three cores 157 were also collected from each of four locations in the surrounding native forest, and divided into $158 \quad 0-10 \mathrm{~cm}$ and $10-30 \mathrm{~cm}$ depths. Soil samples were stored cool at $4^{\circ} \mathrm{C}$ in polyethylene bags until 159 processing in the laboratory. 
161 Soil samples were manually homogenized, air-dried and sieved $(<4.75 \mathrm{~mm}$ diameter $)$ to remove 162 roots, rocks, charcoal and other debris. Bulk density was estimated from the sieved soil as the 163 ratio of sieved oven-dry $\left(105^{\circ} \mathrm{C}\right.$ for 24 hours $)$ soil mass per unit volume of soil core. Total soil C 164 was measured using the combustion furnace technique of an automated $\mathrm{C} / \mathrm{N}$ analyzer (LECO 165 CHN-2000, St. Joseph, Michigan). Soil N and P concentrations were determined to calculate the 166 sizes of soil $\mathrm{N}$ and $\mathrm{P}$ pools at $0-30 \mathrm{~cm}$ depth. To determine soil $\mathrm{N}$ and $\mathrm{P}$ concentrations, ground

167 and dried $\left(60^{\circ} \mathrm{C}\right.$ for 24 hours) soil material was digested in acid (potassium sulphate dissolved in

168 concentrated sulphuric acid) and hydrogen peroxide (modified from (Heffernan 1985). A copper 169 sulphate solution catalyst was added to the soil for $12 \mathrm{~h}$ prior to the digestion. Total $\mathrm{N}$ and $\mathrm{P}$ were 170 determined simultaneously in a continuous flow system (Technicon ${ }^{\circledR}$ TRAACS $800^{\mathrm{TM}}$ or

171 Technicon Auto-Analyser II) using an ascorbic acid/ammonium molybdate method.

173 The mass of the $\mathrm{O}$ horizon was sampled in March 2003. Three forest floor litter samples were 174 collected from the Flat microsite (equidistant from four trees) in each 100E, 50E:50A and 100A

175 plot using $0.25 \mathrm{~m}^{2}$ quadrats. Mineral soil that was accidentally collected was removed by sieving $176(2 \mathrm{~mm})$ before oven drying to constant weight at $50^{\circ} \mathrm{C}$. More information about the sampling 177 strategy can be found in Forrester and others (2005).

\section{Fractionation of particulate organic matter fractions and acid hydrolysis}

180 To examine potential differences in decomposition processes, particulate organic matter (POM) 181 was divided into three density fractions, (i) water floatable, (ii) light fraction (density between 1 182 and $1.23 \mathrm{~g} \mathrm{~cm}^{-3}$ ) and (iii) heavy fraction (density $\left.>1.23 \mathrm{~g} \mathrm{~cm}^{-3}\right)$. Three soil cores $(0-5 \mathrm{~cm} \mathrm{depth})$ 
183 from the Flat microsite per plot were collected in January 2003 and mixed into a single sample

184 per plot. Samples were collected from 100E, 100A and 50E:50A. The soil was sieved moist with

185 a $2 \mathrm{~mm}$ sieve to remove coarse material. The equivalent of $100 \mathrm{~g}$ dry weight of soil was washed

186 over a $63 \mu \mathrm{m}$ sieve. Water floatable POM was recovered by repeated (3-4 times) floatation in

187 water and decanting of material until no more material was recovered. The remaining soil was

188 then suspended in Ludox ${ }^{\mathrm{TM}}$ colloidal silica (Du Pont Industries) to obtain the light fraction.

189 Ludox grade TMA was used, which has a specific gravity of $1.23 \mathrm{~g} \mathrm{~cm}^{-3}$, consists of $34 \%$ silica

190 as $\mathrm{SiO}_{2}$ by weight and has a $\mathrm{pH}$ range of 4 to 7 . This was also repeated about 3-4 times. The

191 heavy fraction POM was material that did not float on Ludox, but sinks much less rapidly than

192 sand. All fractions were washed for several minutes, including the water floatable fraction, for

193 consistency. These samples were dried at $65^{\circ} \mathrm{C}$ for 48 hours, ground, weighed and analyzed for

$194 \mathrm{C}$ and $\mathrm{N}$ using the same methods described above.

196 The percentage of acid-hydrolyzable OM in each density fraction was determined and used as an

197 indicator of decomposability. A $0.1 \mathrm{~g}$ sample of OM was hydrolyzed in concentrated (72\%)

198 sulfuric acid (for 2 hours), then diluted to $2.5 \%$ for 1 hour. The suspension was centrifuged and

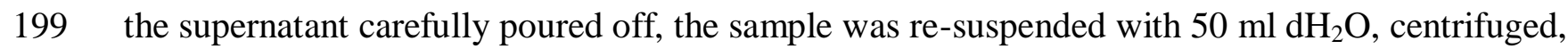

200 supernatant poured off, and this was repeated four times before washing the samples and drying

201 at $105^{\circ} \mathrm{C}$ for 48 hours. Samples were weighed to determine the mass loss. These values were

202 corrected for the ash content, which was determined by combustion at $550^{\circ} \mathrm{C}$ for four hours.

204 Aboveground biomass 
205 Diameter at $1.3 \mathrm{~m}$ was measured in March 2003 on all trees. Aboveground biomass was

206 estimated using an allometric equation for 10-year-old A. mearnsii developed in these stands

207 (Forrester and others 2004), and an equation for E. globulus developed by Veiga (2008) using

208 data from a range of ages, site qualities and initial spacing treatments.

\section{Statistical analysis}

211 Regression analysis was used to examine the relationship between soil $\mathrm{C}$ and aboveground

212 biomass, and the effect of the percentage of $A$. mearnsii in each treatment on soil $\mathrm{C}, \mathrm{N}$ and $\mathrm{P}$. A

213 separate t-test was used to compare E. globulus monocultures that were unfertilized (100E) and

214 fertilized (100Efert). Differences between microsites were tested using Residual Maximum

215 Likelihood analysis (REML) with replicate/treatment as a random effect because there were no

216 interactions between treatment and microsite for any variable. REML was also used to examine

217 treatment effects on particulate organic matter (with replicate as a random effect), because this

218 was measured in three treatments, preventing the use of regression. Standard errors of difference

219 (SEDs) are provided for comparison of treatment means. All analyses were performed in

220 Genstat $^{\mathrm{TM}}$ (VSN Int., Hemel Hemestead, UK).

\section{Results}

224 Soil $\mathrm{C}$ was non-linearly related to the percent of $A$. mearnsii in the treatment, peaking in the

225 mixtures, especially in the 50E:50A treatment (Figure 2). Soil C was higher in all treatments that

226 contained A. mearnsii compared with the native forest or E. globulus monocultures, whether they

227 had been fertilized or not (Figure 2; $P<0.001)$. This treatment effect was attributable to 
228 differences in soil $\mathrm{C}$ at $10-30 \mathrm{~cm}$ depth; there were no significant differences at $0-10 \mathrm{~cm}$ depth.

229 Soil C stocks were highly, positively and linearly correlated with aboveground biomass (Figure

230 3). Microsites significantly influenced soil $\mathrm{C}$, which was highest in the Mounds and lowest in the

231 Flats (Table 2).

232

233 The $\mathrm{N}$ and $\mathrm{P}$ contents of the top $30 \mathrm{~cm}$ of soil were not correlated with the percent of A. mearnsii

234 in the treatments $(P>0.05)$. Instead, soil $\mathrm{N}$ was higher in treatments containing A. mearnsii

235 compared with those that did not $(P=0.002$, Table 1). It was highest in acacia monocultures

236 (100A) and lowest in the fertilized E. globulus monocultures (Table 1). Comparisons between $\mathrm{N}$

237 in mineral soil, the $\mathrm{O}$ horizon and aboveground biomass in 100E compared with 50E:50A or

238 100A suggested that rates of symbiotic $\mathrm{N}_{2}$-fixation were 38 and $86 \mathrm{~kg} \mathrm{ha}^{-1}$ year ${ }^{-1}$ in 50E:50A and

239 100A, respectively, for the first 10 years (Forrester and others 2007). Soil C was not correlated

240 with soil $\mathrm{N}(P=0.527)$ or $\mathrm{P}$ contents $(P=0.310)$ (excluding data for 100Efert and the native forest).

241 There was no significant difference in soil $\mathrm{N}$ or $\mathrm{P}$ between E. globulus monocultures that were

242 fertilized (100Efert) or unfertilized (100E) (Table 1).

$244 \mathrm{C} / \mathrm{P}$ and $\mathrm{N} / \mathrm{P}$ ratios were not related to the percent $A$. mearnsii, but $\mathrm{C} / \mathrm{N}$ ratios at $0-10 \mathrm{~cm}$ were

245 negatively and linearly related to the percent $A$. mearnsii $\left(P=0.03\right.$, Adj. $\mathrm{R}^{2}=0.03, \mathrm{y}=46.19$ -

$2460.15 \mathrm{x}) . \mathrm{C} / \mathrm{N}$ ratios were lower at $0-10 \mathrm{~cm}$ compared with $10-30 \mathrm{~cm}$, whereas $\mathrm{C} / \mathrm{P}$ ratios were

247 lower at 10-30 cm compared with 0-10 $\mathrm{cm}$ (Table 1).

249 Particulate organic matter fractions $(0-5 \mathrm{~cm}$ depth) were highest in $100 \mathrm{~A}$, lowest in $100 \mathrm{E}$ and 250 intermediate in 50E:50A (Figure 4a). The N concentration of this POM was lower in 100E 
251 compared with stands containing A. mearnsii (Figure 4b). There were no treatment effects on $\mathrm{P}$

252 contents of POM. The percent of O horizon mass that was resistant to acid-hydrolysis was higher

253 in 100A compared with $100 \mathrm{E}$ or mixtures. A similar trend occurred for the water floatable

254 fraction of POM, although this was not significant.

255

256 Soil bulk density in the plantation plots increased with depth $(P<0.001)$ from $1.34 \mathrm{~g} \mathrm{~cm}^{-3}$ at $0-10$

$257 \mathrm{~cm}$ to $1.60 \mathrm{~g} \mathrm{~cm}^{-3}$ at $10-30 \mathrm{~cm}$. There were no interactions between treatments and microsites.

258 Bulk density in the Flats, Trenches and Mounds were 1.55, 1.53 and $1.32 \mathrm{~g} \mathrm{~cm}^{-3}$ respectively, but

259 these differences were not significant $(P>0.05)$. There were also no significant treatment effects.

\section{Discussion}

262 Soil C was highest in mixtures and lowest in E. globulus monocultures, whether they were

263 fertilized or not. Higher soil C stocks under $\mathrm{N}_{2}$-fixing species compared with non- $\mathrm{N}_{2}$-fixing

264 species have been reported previously (Kaye and others 2000; Johnson and Curtis 2001; Resh

265 and others 2002; Binkley 2005; Jeddi and others 2009; Wang and others 2010). However, the

266 effects of mixtures on soil C stocks have rarely been examined. Here, C stocks were not linearly

267 related to the proportion of A. mearnsii. Soil $\mathrm{C}$ was highly positively correlated with above-

268 ground biomass, and because mixtures were significantly more productive than monocultures,

269 soil $\mathrm{C}$ was also highest in mixtures.

270

271 Higher soil $\mathbf{C}$ under mixtures than monocultures

272 The 50E:50A mixtures had greater $\mathrm{C}$ inputs into soil (process 1 in Figure 1) than monocultures in

273 terms of litterfall and total belowground $\mathrm{C}$ allocation, although the latter was not significantly 
274 different (Table 4). Increased $\mathrm{C}$ inputs were not the only process influencing soil $\mathrm{C}$ in these

275 mixed stands. Rates of litter decomposition as well as litter $\mathrm{N}$ and $\mathrm{P}$ contents and concentrations,

276 all increased with the proportion of $A$. mearnsii (Table 4; Forrester and others 2005). Depending

277 on the fate of $\mathrm{C}$ in the $\mathrm{O}$ horizon, the more rapid decomposition could indicate that more $\mathrm{C}$ was

278 incorporated into the mineral soil (process 3) but might also have had the opposite effect on soil

$279 \mathrm{C}$ if more of the $\mathrm{O}$ horizon $\mathrm{C}$ was lost to the atmosphere as $\mathrm{CO}_{2}$ (process $2 \mathrm{a}$ ). The mass of all $\mathrm{OM}$

280 density fractions in the top $0-5 \mathrm{~cm}$ (and their $\mathrm{N}$ concentrations) increased with increasing

281 proportions of $A$. mearnsii, indicating that a greater proportion of $\mathrm{O}$ horizon $\mathrm{C}$ was incorporated

282 into mineral soil beneath $\mathrm{N}$-fixing trees to increase soil C at this depth (process 3). Similarly,

283 increases in soil $\mathrm{C}$ under $F$. moluccana compared with E. saligna resulted from an increase in

284 new tree-derived $\mathrm{C}$ and not only reduced decomposition of older $\mathrm{C}$ derived from the previous

285 sugar cane cropping system (Kaye and others 2000).

287 Although early stages of OM decomposition usually proceed faster for litter with higher $\mathrm{N}$ 288 concentrations (2a), the later stages of decomposition can be decelerated (2b) (Berg 2000; Neff

289 and others 2002; Prescott 2010) thereby increasing soil C. In this study, the mass of all OM

290 fractions $(0-5 \mathrm{~cm})$ increased, and had higher $\mathrm{N}$ concentrations, as the proportions of $A$. mearnsii

291 increased. The decomposability, as indicated by the percentage of acid-hydrolyzable OM, also

292 tended to decrease as the proportion of $A$. mearnsii increased. This suggests that OM in stands

293 with the $\mathrm{N}_{2}$-fixing $A$. mearnsii is more protected or complexed and thus harder for decomposers

294 to break down. Root C may contribute more to soil C stocks because it may be less accessible to

295 decomposers (Post and Kwon 2000; Prescott 2010; Schmidt and others 2011). The significant

296 increases in OM in the 0-5 cm depth might be influenced by aboveground litter inputs as well as 
297 fine-roots. However, root inputs are more likely to dominate soil $\mathrm{C}$ in the $10-30 \mathrm{~cm}$ soil layer,

298 and the changes in soil C at this depth led to the higher soil C stocks in mixtures compared with

299 monocultures. Thus, inputs from roots (process 1) and/or reductions in their decomposition

300 (process $2 \mathrm{~b}$ ) were probably important mechanisms in these stands. Further support for this

301 assumption is higher soil $\mathrm{C}$ in mounds, which likely represent a better rooting substrate than the

302 other microsites, whereas litter-fall would not have been different between microsites in these

303 stands were the canopy closed very rapidly. $\mathrm{N}$ concentrations in fine-roots of A. mearnsii were

304 rather constant, at around $0.9 \mathrm{mg} \mathrm{g}^{-1}$, whereas those of E. globulus increased from $0.2 \mathrm{mg} \mathrm{g}^{-1}$ in

305 monocultures to $0.6 \mathrm{mg} \mathrm{g}^{-1}$ in the 50E:50A mixture (Bauhus and others 2000). Therefore, the

306 higher soil $\mathrm{C}$ of mixtures was likely the net effect of (i) higher $\mathrm{C}$ inputs (process 1) resulting from

307 synergistic interactions between species that increased above- and belowground productivity, (ii)

308 reduced rates of decomposition of soil $\mathrm{C}$ (process $2 \mathrm{~b}$ ) with increasing proportions of $\mathrm{A}$. mearnsii

309 or (iii) a faster rate of conversion of $\mathrm{O}$ horizon $\mathrm{C}$ to mineral soil $\mathrm{C}$ with increasing proportions of

310 A. mearnsii.

312 The application of fertilizer $\mathrm{N}$ did not increase soil C. Similarly, application of $600 \mathrm{~kg} \mathrm{ha}^{-1}$ of

313 fertilizer $\mathrm{N}$ over six years did not increase soil $\mathrm{C}$ under E. saligna plantations (Binkley and others

314 2004), even though $\mathrm{N}$ fixed by F. molucanna on the same soils did increase soil C (Kaye and

315 others 2000). Hence, it was concluded that the increase in soil C was not simply the result of a

316 chemical reaction in response to the increased availability of inorganic $\mathrm{N}$ (Binkley and others

317 2004; Binkley 2005). Schmidt and others (2011) propose that organic matter persists because

318 physicochemical and biological influences reduce rates of decomposition and enable OM to

319 persist. That is, the persistence of OM is an ecosystem property more than the result of any 
320 intrinsic property of OM itself. Mixtures also had lower soil moisture due to greater growth and

321 evapotranspiration (Forrester and others 2010), and P pools and fluxes also varied with the

322 proportion of $A$. mearnsii (Forrester and others 2005), and these characteristics might also have

323 modified soil ecological processes in a way that contributed to the soil $\mathrm{C}$ dynamics in these

324 stands.

326 Increasing soil $\mathbf{C}$ with increasing proportions of $\mathbf{N}_{\mathbf{2}}$-fixing species

327 In contrast to this study, where soil $\mathrm{C}$ was highest in the mixtures, others have found that soil $\mathrm{C}$

328 increased with the proportion of the $\mathrm{N}_{2}$-fixing species. Although the same processes in Figure 1

329 are likely to occur in each study, their relative contributions vary. For example, soil organic C

330 down to a depth of $50 \mathrm{~cm}$ was also examined in 17-year-old mixed and monospecific stands of

331 E. saligna and $F$. moluccana (=Albizia falcataria, an $\mathrm{N}_{2}$-fixing species) in Hawaii planted on an

332 ex-sugar cane site (Kaye and others 2000). Aboveground biomass and C were highest in mixtures

333 and lowest in monocultures, which is consistent with this study. However in contrast to this

334 study, soil C increased with the proportion of $F$. moluccana. Thus although the same processes

335 are likely to have occurred as in our study (Figure 1), their relative influence must have been

336 different. Higher soil C under F. moluccana than E. saligna was caused by reduced

337 decomposition of older (sugar cane derived) $\mathrm{C}$ as well as an increase in new (tree-derived) $\mathrm{C}$

338 (Kaye and others 2000), which is consistent with our results. The new (tree-derived) C

339 decomposed as fast or faster under F. moluccana than E. saligna (Resh and others 2002).

340 Litterfall was similar in each monoculture, however, total belowground C allocation was higher

341 for monocultures of $F$. moluccana than E. saligna (Binkley and Ryan 1998). The latter contrasts

342 with this study, where both fluxes did not significantly differ between monocultures (Table 4; 
343 Forrester and others 2006a). This is an important difference between the studies because below-

344 ground C inputs might be even more important than aboveground inputs for increasing soil C

345 (Post and Kwon 2000; Prescott 2010; Schmidt and others 2011).

347 Mixtures of Pinus banksiana and Alnus crispa also had a greater aboveground biomass and $\mathrm{O}$

348 horizon C compared with $P$. banksiana stands that regenerated without the $\mathrm{N}_{2}$-fixing A. crispa,

349 however, increases in soil C were not significant (Vogel and Gower 1998). Soil C was also not

350 significantly different in E. grandis and A. mangium mixtures and monocultures (Voigtlaender

351 and others 2011). Stem and coarse-root mass were greatest in E. grandis monocultures,

352 intermediate in 50E:50A mixtures and lowest in A. mangium monocultures (Laclau and others

353 2008). In these mixtures, A. mangium was suppressed by E. grandis. Thus in contrast to this

354 study there may have been decreasing $\mathrm{C}$ inputs (process 1) with increasing proportions of

355 A. mangium, which would have worked against a possible increase in soil C.

357 In conclusion, soil C was linearly correlated with aboveground productivity and not with the

358 proportion of the $\mathrm{N}_{2}$-fixing species. The soil C stocks were the net effect of several (sometimes

359 opposing) mechanisms that varied in importance between this and previously published

360 experiments, resulting in contrasting mixture effects on soil C. The A. mearnsii effect was not

361 due to $\mathrm{N}$ per se, because the application of fertilizer $\mathrm{N}$ did not change soil $\mathrm{C}$. The potential to

362 increase soil $\mathrm{C}$ using mixtures warrants more attention, and because changes in soil $\mathrm{C}$ were

363 greatest in the 10-30 $\mathrm{cm}$ depth, sampling to at least this depth, and preferably deeper would be 364 useful. 


\section{Acknowledgements}

367 We wish to thank John Smith and Vijay Koul for assistance in the field and with soil processing.

368 The experiment was established by the Commonwealth Scientific and Industrial Research

369 Organisation, Division of Forestry, with the Department of Natural Resources and Environment,

370 Victoria, providing the site and the Australian Centre for International Agricultural Research

371 providing some financial support. Thank you also to two anonymous reviewers who provided

372 useful comments that improved the manuscript.

373

\section{References}

375 Bauhus J, Khanna PK and Menden N. 2000. Aboveground and belowground interactions in mixed plantations of Eucalyptus globulus and Acacia mearnsii. Canadian Journal of Forest Research 30: 1886-1894.

Berg B. 2000. Litter decomposition and organic matter turnover in northern forest soils. Forest Ecology and Management 133: 13-22.

Binkley D. 2005. How nitrogen-fixing trees change soil carbon. Binkley D and Menyailo O. Tree Dordrecht: Kluwer Academic Publishers. p155-164.

Binkley D and Giardina C. 1998 Why trees affect soils in temperate and tropical forests: the warp and woof of tree/soil interactions. Biogeochemistry 42: 89-106. 68: 1713-1719. 
Binkley D and Ryan MG. 1998. Net primary production and nutrient cycling in replicated stands of Eucalyptus saligna and Albizia facaltaria. Forest Ecology and Management 112: 7985.

Canadell JG and Raupach MR. 2008. Managing forests for climate change mitigation. Science 320: 1456-1457.

Costermans LF. 1983. Native trees and shrubs of south-eastern Australia. Rigby, Adelaide, 422 p.Dungait JAJ, Hopkins DW, Gregory AS and Whitmore AP. 2012. Soil organic matter turnover is governed by accessibility not recalcitrance. Global Change Biology 18: 17811796.

Forrester DI, Bauhus J and Cowie AL. 2005. Nutrient cycling in a mixed-species plantation of Eucalyptus globulus and Acacia mearnsii. Canadian Journal of Forest Research 35: 29422950.

Forrester DI, Bauhus J and Cowie AL. 2006a. Carbon allocation in a mixed-species plantation of Eucalyptus globulus and Acacia mearnsii. Forest Ecology and Management 233: 275284.

Forrester DI, Bauhus J, Cowie AL and Vanclay JK. 2006b. Mixed-species plantations of Eucalyptus with nitrogen fixing trees: A review. Forest Ecology and Management 233: 211-230.

Forrester DI, Bauhus J and Khanna PK. 2004. Growth dynamics in a mixed-species plantation of Eucalyptus globulus and Acacia mearnsii. Forest Ecology and Management 193: 81-95.

Forrester DI, Schortemeyer M, Stock WD, Bauhus J, Khanna PK and Cowie AL. 2007. Assessing nitrogen fixation in mixed- and single-species plantations of Eucalyptus globulus and Acacia mearnsii. Tree Physiology 27: 1319-1328. 
411 Forrester DI, Theiveyanathan S, Collopy JJ and Marcar NE. 2010. Enhanced water use efficiency in a mixed Eucalyptus globulus and Acacia mearnsii plantation. Forest Ecology and Management 259: 1761-1770.

414 Gregorich EG, Drury CF and Baldock JA. 2001. Changes in soil carbon under long-term maize in monoculture and legume-based rotation. Canadian Journal of Soil Science 81: 21-31.

Heffernan B. 1985. A handbook of methods of inorganic chemical analysis for forest soils, foliage and water. Canberra: CSIRO Division of Forest Research. 281 p.

Isbell RF. 1998. The Australian soil classification. Collingwood: CSIRO Publishing. 143 p.

419 Jeddi K, Cortina J and Chaieb M. 2009. Acacia salicina, Pinus halepensis and Eucalyptus occidentalis improve soil surface conditions in arid southern Tunisia. Journal of Arid Environments 73: 1005-1013.

Johnson DW and Curtis PS. 2001. Effects of forest management on soil C and N storage: meta analysis. Forest Ecology and Management 140: 227-238.

424 Kaye JP, Resh SC, Kaye MW and Chimmer RA. 2000. Nutrient and carbon dynamics in a 425 replacement series of Eucalyptus and Albizia trees. Ecology 81: 3267-3273.

426 Laclau J-P, Bouillet J-P, Gonçalves JLM, Silva EV, Jourdan C, Cunha MCS, Moreira MR, SaintAndré L, Maquère V, Nouvellon Y and Ranger J. 2008. Mixed-species plantations of Acacia mangium and Eucalyptus grandis in Brazil 1. Growth dynamics and aboveground net primary production. Forest Ecology and Management 255: 3905-3917.

430 Mao R, Zeng D-H, Ai G-Y, Yang D, Li L-J and Liu Y-X. 2010. Soil microbiological and chemical effects of a nitrogen-fixing shrub in poplar plantations in semi-arid region of Northeast China. European Journal of Soil Biology 46: 325-329. 
433 Neff JC, Townsend AR, Gleixner G, Lehmans SJ, Turnball J and Bowman WD. 2002. Variable

434 effects of nitrogen additions on the stability and turnover of soil carbon. Nature 419: 915-

435917.

436 Paul KI, Polglase PJ, Nyakuengama JG and Khanna PK. 2002. Change in soil carbon following 437 afforestation. Forest Ecology and Management 168: 241-257.

438 Post WM and Kwon KC. 2000. Soil carbon sequestration and land-use change: processes and 439 potential. Global Change Biology 6: 317-327.

440 Prescott CE. 2010. Litter decomposition: what controls it and how can we alter it to sequester $441 \quad$ more carbon in forest soils? Biogeochemistry 101: 133-149.

442 Resh SC, Binkley D and Parrotta JA. 2002. Greater soil carbon sequestration under nitrogen443 fixing trees compared with Eucalyptus species. Ecosystems 5: 217-231.

444 Russell AE, Cambardella CA, Ewel JJ and Parkin TB. 2004. Species, rotation, and life-form 445 diversity effects on soil carbon in experimental tropical ecosystems. Ecological $446 \quad$ Applications 14: 47-60.

447 Schmidt MWI, Torn MS, Abiven S, Dittmar T, Guggenberger G, Janssens IA, Kleber M, Kögel448 Knabner I, Lehmann J, Manning DAC, Nannipieri P, Rasse DP, Weiner S and Trumbore 449 SE. 2011. Persistence of soil organic matter as an ecosystem property. Nature 478: 49-56.

450 Stace HCT, Hubble GD, Brewer R, Northcote KH, Sleeman JR, Mulcahy MJ and Hallsworth EG. 451 1968. A handbook of Australian soils. Glenside, S.A., Australia: Rellim. 435 p.

452 Taylor BR, Prescott CE, Parsons JF and Parkinson D. 1991. Substrate control of litter 453 decomposition in four Rocky Mountain coniferous forests. Canadian Journal of Botany $454 \quad 69: 2242-2250$. 
455 Veiga PR. 2008. Allometric Biomass Equations for Plantations of Eucalyptus globulus and

456 Eucalyptus nitens in Australia. Masters Thesis. Albert-Ludwigs University Freiburg, $457 \quad$ Faculty of Forest and Environmental Sciences. 74 p.

458 Vogel JG and Gower ST. 1998. Carbon and nitrogen dynamics of boreal jack pine stands with 459 and without a green alder understorey. Ecosystems 1: 386-400.

460 Voigtlaender M, Laclau J-P, Gonçalves JLdM, Piccolo MdC, Moreira MZ, Nouvellon Y, Ranger

$461 \quad \mathrm{~J}$ and Bouillet J-P. 2011. Introducing Acacia mangium trees in Eucalyptus grandis

462 plantations: consequences for soil organic matter stocks and nitrogen mineralization.

$463 \quad$ Plant and Soil 352: 99-111.

464 Wang F, Li Z, Xia H, Zou B, Li N, Liu J and Zhu W. 2010. Effects of nitrogen-fixing and non465 nitrogen-fixing tree species on soil properties and nitrogen transformations during forest 466 restoration in southern China. Soil Science and Plant Nutrition 56: 297-306.

467 Wang Q, Wang S and Zhang J. 2009. Assessing the effects of vegetation types on carbon storage 468 fifteen years after reforestation on a Chinese fir site. Forest Ecology and Management 469 258: 1437-1441.

470

471

472

473 
Table 1. Mineral Soil N, P and Soil C/N, C/P and N/P Ratios in the Mixtures (25E:75A, 50E:50A, 75E:25A), Unfertilized Monocultures (100A, 100E), Fertilized Monoculture (100Efert) and Adjacent Native Forest (Nfst), 8.3 Years after Planting

\begin{tabular}{llccccccccc}
\hline & DEPTH & $100 \mathrm{~A}$ & $25 \mathrm{E}: 75 \mathrm{~A}$ & $50 \mathrm{E}: 50 \mathrm{~A}$ & $75 \mathrm{E}: 25 \mathrm{~A}$ & $100 \mathrm{E}$ & $100 \mathrm{Efert}$ & Nfst & SED & F. prob. \\
\hline Soil N $\left(\mathrm{kg} \mathrm{ha}^{-1}\right)$ & $0-10 \mathrm{~cm}$ & 1150 & 798 & 693 & 858 & 712 & 552 & & 112 & $<0.001$ \\
& $10-30 \mathrm{~cm}$ & 837 & 780 & 868 & 1014 & 781 & 619 & & 83 & 0.001 \\
& $0-30 \mathrm{~cm}$ & 1987 & 1578 & 1561 & 1872 & 1493 & 1171 & 1484 & 179 & 0.002 \\
\hline Soil P $\left(\mathrm{kg} \mathrm{ha}^{-1}\right)$ & $0-10 \mathrm{~cm}$ & 58.1 & 56.7 & 53.2 & 70.8 & 49.7 & 62.5 & & 13.3 & 0.638 \\
& $10-30 \mathrm{~cm}$ & 195.7 & 154.7 & 164.2 & 104.9 & 156.2 & 177.7 & 32.8 & 0.120 \\
& $0-30 \mathrm{~cm}$ & 253.8 & 211.4 & 217.4 & 175.7 & 205.9 & 240.2 & 186.7 & 33.9 & 0.342 \\
\hline $\mathrm{C} / \mathrm{N}\left(\mathrm{kg} \mathrm{kg}^{-1}\right)$ & $0-10 \mathrm{~cm}$ & 31.4 & 35.5 & 42.0 & 38.8 & 42.2 & 52.5 & & 7.2 & 0.107 \\
& $10-30 \mathrm{~cm}$ & 55.3 & 70.6 & 65.7 & 51.1 & 49.5 & 58.4 & & 7.3 & 0.034 \\
& $0-30 \mathrm{~cm}$ & 40.8 & 52.8 & 55.1 & 43.8 & 44.9 & 54.8 & 48.1 & 5.6 & 0.101 \\
\hline $\mathrm{C} / \mathrm{P}\left(\mathrm{kg} \mathrm{kg}^{-1}\right)$ & $0-10 \mathrm{~cm}$ & 651 & 475 & 547 & 483 & 604 & 481 & & 65.8 & 0.046 \\
& $10-30 \mathrm{~cm}$ & 258 & 382 & 380 & 528 & 292 & 229 & 60.9 & $<0.001$ \\
& $0-30 \mathrm{~cm}$ & 346 & 401 & 417 & 475 & 362 & 280 & 372 & 56.0 & 0.045 \\
\hline $\mathrm{N} / \mathrm{P}\left(\mathrm{kg} \mathrm{kg}^{-1}\right)$ & $0-10 \mathrm{~cm}$ & 21.7 & 14.4 & 13.2 & 14.1 & 15.1 & 10.3 & & 2.5 & 0.003 \\
& $10-30 \mathrm{~cm}$ & 4.6 & 5.4 & 6.2 & 10.7 & 6.6 & 3.9 & & 1.3 & $<0.001$ \\
& $0-30 \mathrm{~cm}$ & 8.5 & 7.8 & 7.9 & 11.3 & 8.2 & 5.1 & 8.2 & 1.2 & 0.002
\end{tabular}

$\overline{\mathrm{SED}}=$ standard error of difference. Native forest data were not included in depth analysis. $\mathrm{n}=8$ except for $100 \mathrm{~A}$ where $\mathrm{n}=6$. 
Table 2. Soil C, Soil N and Soil P in the Flat, Mound and Trench Microsites (0-30 cm depth) (excluding Nfst plots) 8.3 Years after Planting

\begin{tabular}{lccccc}
\hline & Flat & Mound & Trench & SED & F prob. \\
\hline Soil C $\left(\mathrm{Mg} \mathrm{ha}^{-1}\right)$ & 71.8 & 83.4 & 66.1 & 4.6 & 0.001 \\
Soil N $\left(\mathrm{kg} \mathrm{ha}^{-1}\right)$ & 1516 & 1689 & 1555 & 77.4 & 0.069 \\
Soil P $\left(\mathrm{kg} \mathrm{ha}^{-1}\right)$ & 206.3 & 208.8 & 240.3 & 19.0 & 0.141 \\
\hline
\end{tabular}

SED $=$ standard error of difference. $n=46$. 
Table 3. P Concentration of Particulate Organic Matter (POM), and the Percent of AcidHydrolysable Organic Matter in Different Density Fractions of Surface Soil $(0-5 \mathrm{~cm})$ at Age 10.5 Years

\begin{tabular}{lccccc}
\hline & 100A & 50E:50A & $100 \mathrm{E}$ & SED & F prob. \\
\hline \multirow{2}{*}{ Water floatable } & P concentration of OM $\left(\mathrm{mg} \mathrm{g}^{-1}\right)$ & & & \\
Ludox light fraction & 245 & 235 & 267 & 11.5 & 0.051 \\
Ludox heavy fraction & 214 & 232 & 241 & 13.7 & 0.257 \\
\hline \multirow{2}{*}{ Percent of acid-hydrolysis resistant organic matter } & & \\
O horizon & 60.2 & 46.6 & 44.6 & 4.3 & 0.025 \\
Water floatable & 54.7 & 42.9 & 42.1 & 4.5 & 0.063 \\
Ludox light fraction & 62.2 & 64.6 & 62.8 & 4.2 & 0.844 \\
Ludox heavy fraction & 73.3 & 62.2 & 64.5 & 5.7 & 0.225 \\
\hline
\end{tabular}

SED $=$ standard error of difference. $n=4$, except 100A where $n=3$. 
Table 4. Aboveground Biomass (age 10.7 years), Litterfall and O Horizon Characteristics (age 9.25 to 11.25 years), Fine-root Biomass (age 6.5 years), Total Belowground C Allocation (during year 11) and N Fixation (to age 10 years)

\begin{tabular}{|c|c|c|c|c|c|c|}
\hline & $100 \mathrm{E}$ & $75 \mathrm{E}: 25 \mathrm{~A}$ & 50E:50A & 25E:75A & $100 \mathrm{~A}$ & 100Efert \\
\hline \multicolumn{7}{|l|}{ Above-ground biomass } \\
\hline$\left(\mathrm{Mg} \mathrm{ha}^{-1}\right)$ & $43.4 \mathrm{a}$ & $91.8 b c$ & $99.1 \mathrm{c}$ & $91.6 \mathrm{c}$ & $75.3 b$ & 182.4 \\
\hline Litterfall $\left(\mathrm{Mg} \mathrm{ha}^{-1} \mathrm{y}^{-1}\right)^{1}$ & $2.43 \mathrm{a}$ & $3.56 \mathrm{~b}$ & $3.74 b$ & $3.69 b$ & $3.29 \mathrm{~b}$ & 3.05 \\
\hline $\mathrm{N}$ in litterfall $\left(\mathrm{kg} \mathrm{ha}^{-1} \mathrm{y}^{-1}\right)^{1}$ & $13.7 \mathrm{a}$ & $31.6 b$ & $39.2 \mathrm{bc}$ & $46.6 \mathrm{~cd}$ & $48.8 \mathrm{~d}$ & 17.6 \\
\hline$P$ in litterfall $\left(\mathrm{kg} \mathrm{ha}^{-1} \mathrm{y}^{-1}\right)^{1}$ & $0.458 \mathrm{a}$ & $0.685 \mathrm{ab}$ & $0.800 \mathrm{~b}$ & $0.829 b$ & $0.741 b$ & 0.838 \\
\hline O horizon $\left(\mathrm{Mg} \mathrm{ha}^{-1}\right)^{1}$ & $7.32 \mathrm{a}$ & & $6.27 \mathrm{a}$ & & $3.53 \mathrm{~b}$ & 9.34 \\
\hline O horizon $\mathrm{N}\left(\mathrm{kg} \mathrm{ha}^{-1}\right)^{1}$ & $50.1 \mathrm{a}$ & & $49.6 \mathrm{a}$ & & $48.1 \mathrm{a}$ & \\
\hline O horizon $\mathrm{P}\left(\mathrm{kg} \mathrm{ha}^{-1}\right)^{1}$ & $1.164 a$ & & $0.937 b$ & & $0.584 \mathrm{c}$ & \\
\hline \multicolumn{7}{|l|}{ Rate of litter decomposition } \\
\hline$\left(y^{-1}\right)^{1}$ & $0.32 \mathrm{a}$ & & $0.56 \mathrm{~b}$ & & $0.85 \mathrm{c}$ & 0.33 \\
\hline \multicolumn{7}{|c|}{ Live fine-root mass $(0-30 \mathrm{~cm})$} \\
\hline$\left(\mathrm{Mg} \mathrm{ha}^{-1}\right)^{2}$ & 4.06 & 4.99 & 5.19 & 4.30 & 4.90 & \\
\hline \multicolumn{7}{|c|}{ Total below-ground $\mathrm{C}$ allocation } \\
\hline$\left(\mathrm{Mg} \mathrm{ha}^{-1} \text { year }^{-1}\right)^{3}$ & $14.604 \mathrm{a}$ & & $16.310 \mathrm{a}$ & & $15.846 a$ & \\
\hline $\mathrm{N}_{2}$-fixed $\left(\mathrm{kg} \mathrm{ha}^{-1} \text { year }^{-1}\right)^{4}$ & & & 38.3 & & 86.2 & \\
\hline
\end{tabular}

For a given variable, means sharing the same letter are not significantly different $(P>0.05$, REML). 100Efert was not included in the analyses. 


\section{Figure captions}

Figure 1. The pools and fluxes of soil C, modified from Binkley (2005). Soil C could increase if detritus inputs increase (1), rates of decomposition decrease (2a, 2b), or by increasing humus formation (3). Detritus inputs (1) may come from aboveground (for example, leaf litter) or belowground sources (for example, fine-roots). The constraint is that $1=(2 a+2 b+3)+$ plus any change in mass of the recent detrital $\mathrm{C}$ pool.

Figure 2. Soil $\mathrm{C}$ at two depths $(0-10 \mathrm{~cm}$ or $10-30 \mathrm{~cm})$ and their sum $(0-30 \mathrm{~cm})$ at age 8.3 years. Error bars are \pm 1 se of the mean. For each point $n=8$ except for $100 \mathrm{~A}$ where $n=6$. There were no differences (t-test) between $100 \mathrm{E}$ and $100 \mathrm{Efert}$ at $0-30 \mathrm{~cm}(P=0.172), 0-10 \mathrm{~cm}(P=0.086)$ or $10-30 \mathrm{~cm}(P=0.741)$.

Figure 3. Relationship between soil C $(0-30 \mathrm{~cm})$ at age 8.3 years and aboveground biomass in mixtures and monocultures of E. globulus and A. mearnsii measured at age 10.7 years. Black points (and line) are soil $\mathrm{C}$ without the $\mathrm{O}$ horizon, and grey dots are soil $\mathrm{C}$ including $\mathrm{C}$ in the $\mathrm{O}$ horizon.

Figure 4. Density fractions of particulate organic matter $(<2 \mathrm{~mm})$ at $0-5 \mathrm{~cm}$ depth (a) and $\mathrm{N}$ concentrations of that POM (b) at age 10.1 years. Means for a given density fraction sharing the same letter are not significantly different at $P<0.05$ (REML). $\mathrm{n}=4$ for each bar, except $100 \mathrm{~A}$ where $n=3$. 
Figure 1. The pools and fluxes of soil C, modified from Binkley (2005). Soil C could increase if detritus inputs increase (1), rates of decomposition decrease (2a, 2b), or by increasing humus formation (3). Detritus inputs (1) may come from aboveground (for example, leaf litter) or belowground sources (for example, fine-roots). The constraint is that $1=(2 a+2 b+3)+$ plus any change in mass of the recent detrital $\mathrm{C}$ pool.

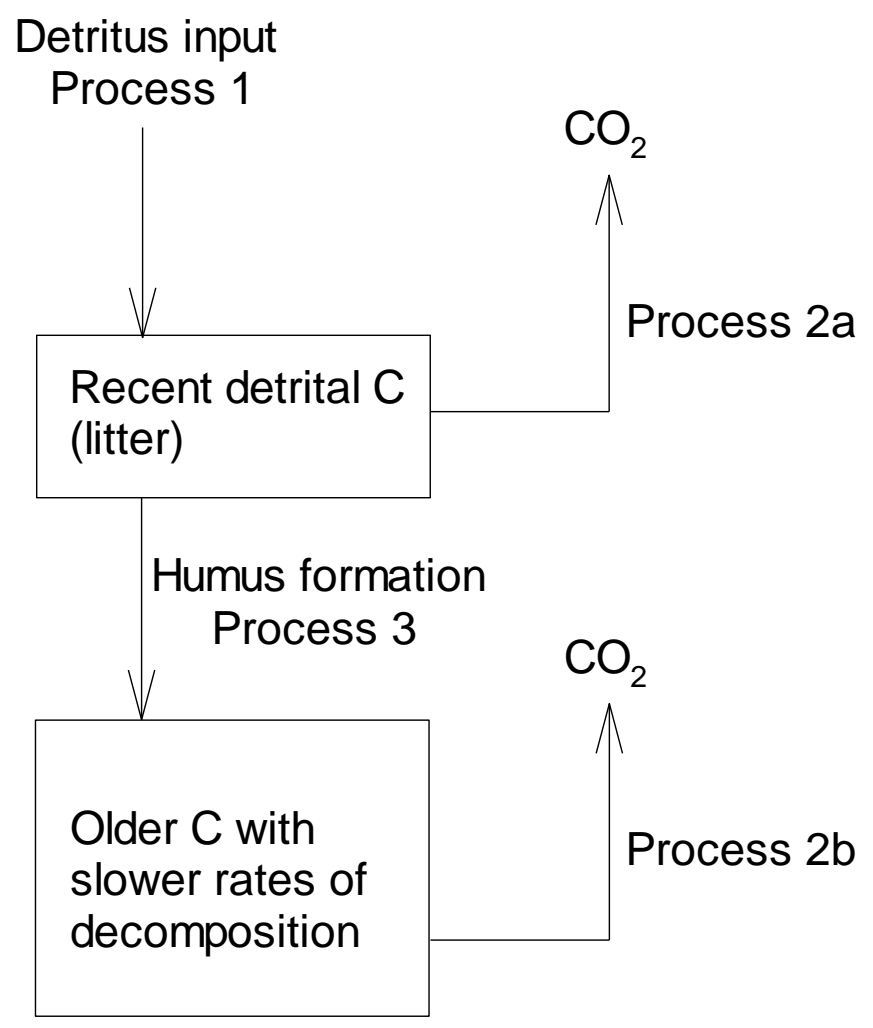


Figure 2. Soil $\mathrm{C}$ at two depths $(0-10 \mathrm{~cm}$ or $10-30 \mathrm{~cm})$ and their sum $(0-30 \mathrm{~cm})$ at age 8.3 years. Error bars are \pm 1 se of the mean. For each point $n=8$ except for $100 \mathrm{~A}$ where $n=6$. There were no differences (t-test) between $100 \mathrm{E}$ and 100Efert at $0-30 \mathrm{~cm}(P=0.172), 0-10 \mathrm{~cm}(P=0.086)$ or $10-30 \mathrm{~cm}(P=0.741)$.

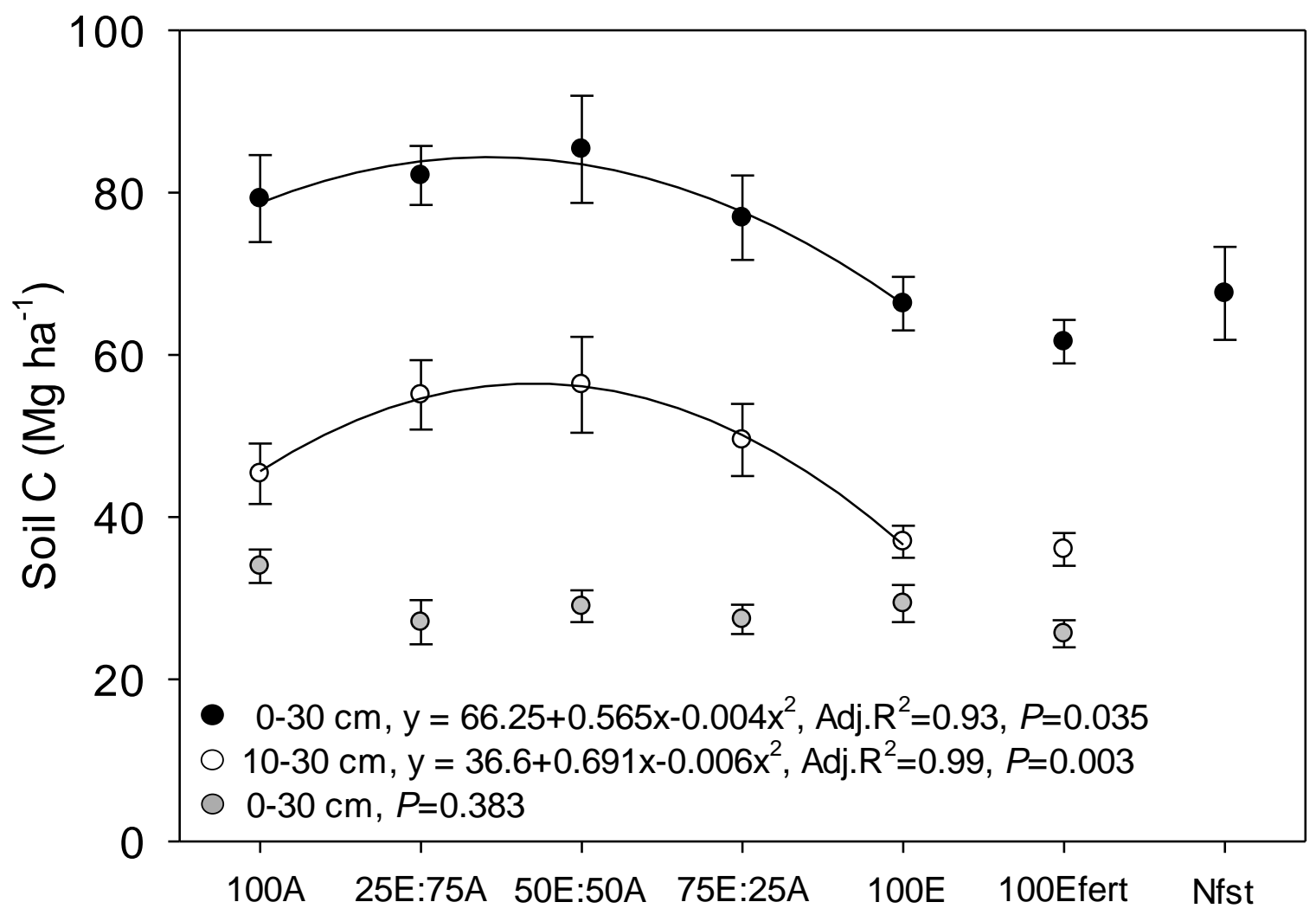


Figure 3. Relationship between soil C $(0-30 \mathrm{~cm})$ at age 8.3 years and aboveground biomass in mixtures and monocultures of E. globulus and A. mearnsii measured at age 10.7 years. Black points (and line) are soil $\mathrm{C}$ without the $\mathrm{O}$ horizon, and grey dots are soil $\mathrm{C}$ including $\mathrm{C}$ in the $\mathrm{O}$ horizon.

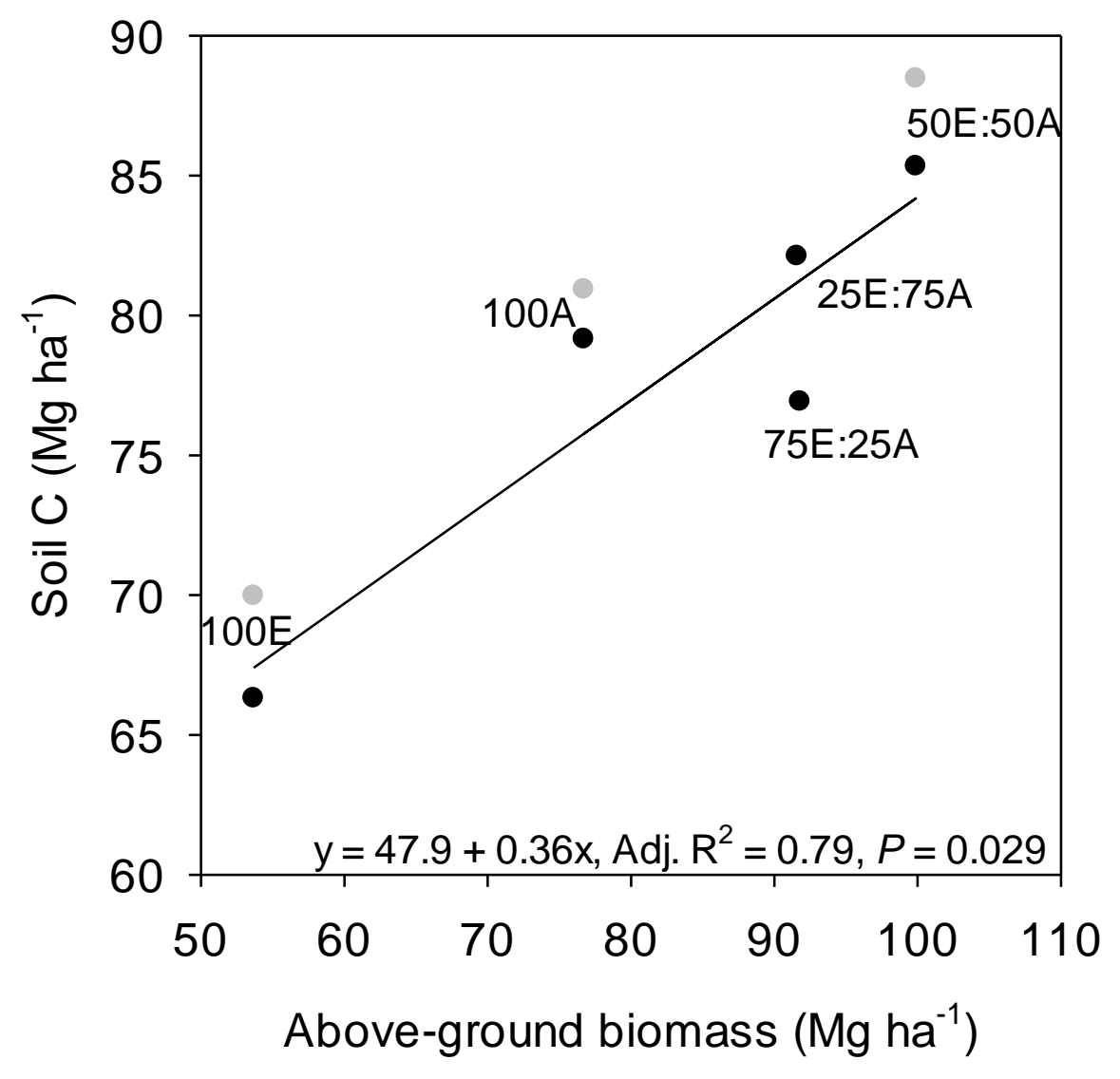


Figure 4. Density fractions of particulate organic matter ( $<2 \mathrm{~mm})$ at $0-5 \mathrm{~cm}$ depth (a) and $\mathrm{N}$ concentrations of that POM (b) at age 10.5 years. Means for a given density fraction sharing the same letter are not significantly different at $P<0.05$ (REML). $\mathrm{n}=4$ for each bar, except 100A where $\mathrm{n}=3$.

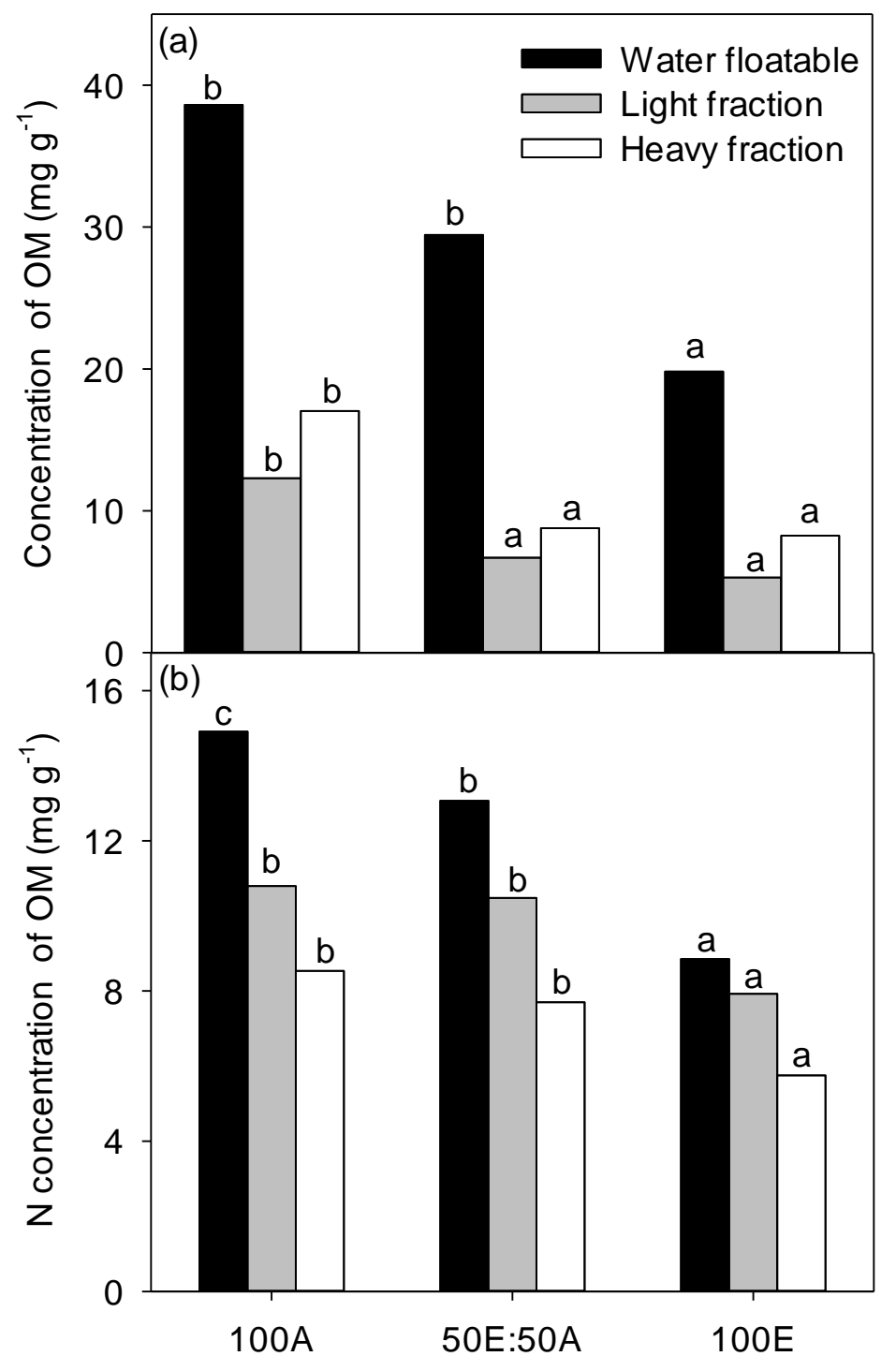



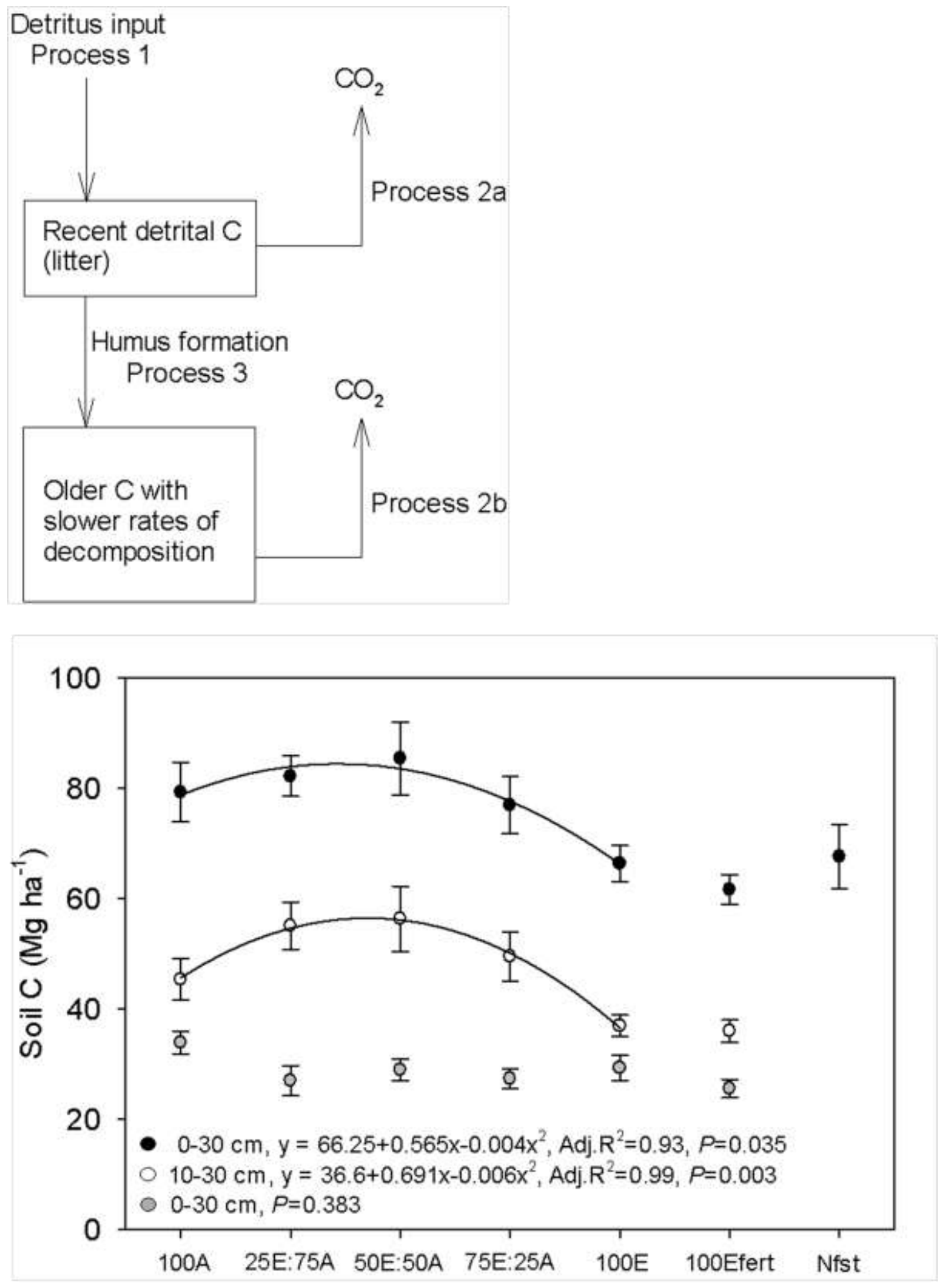


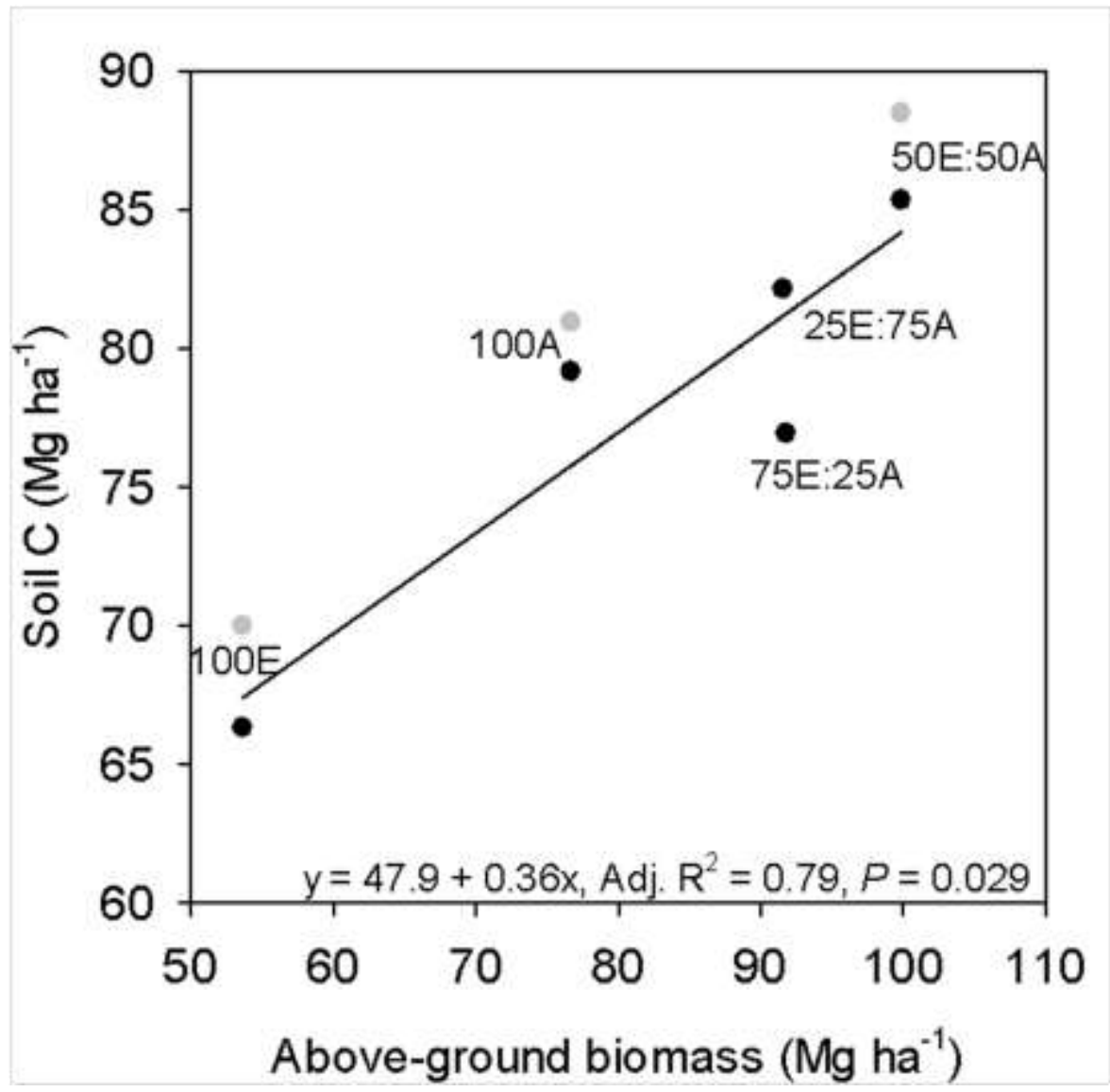




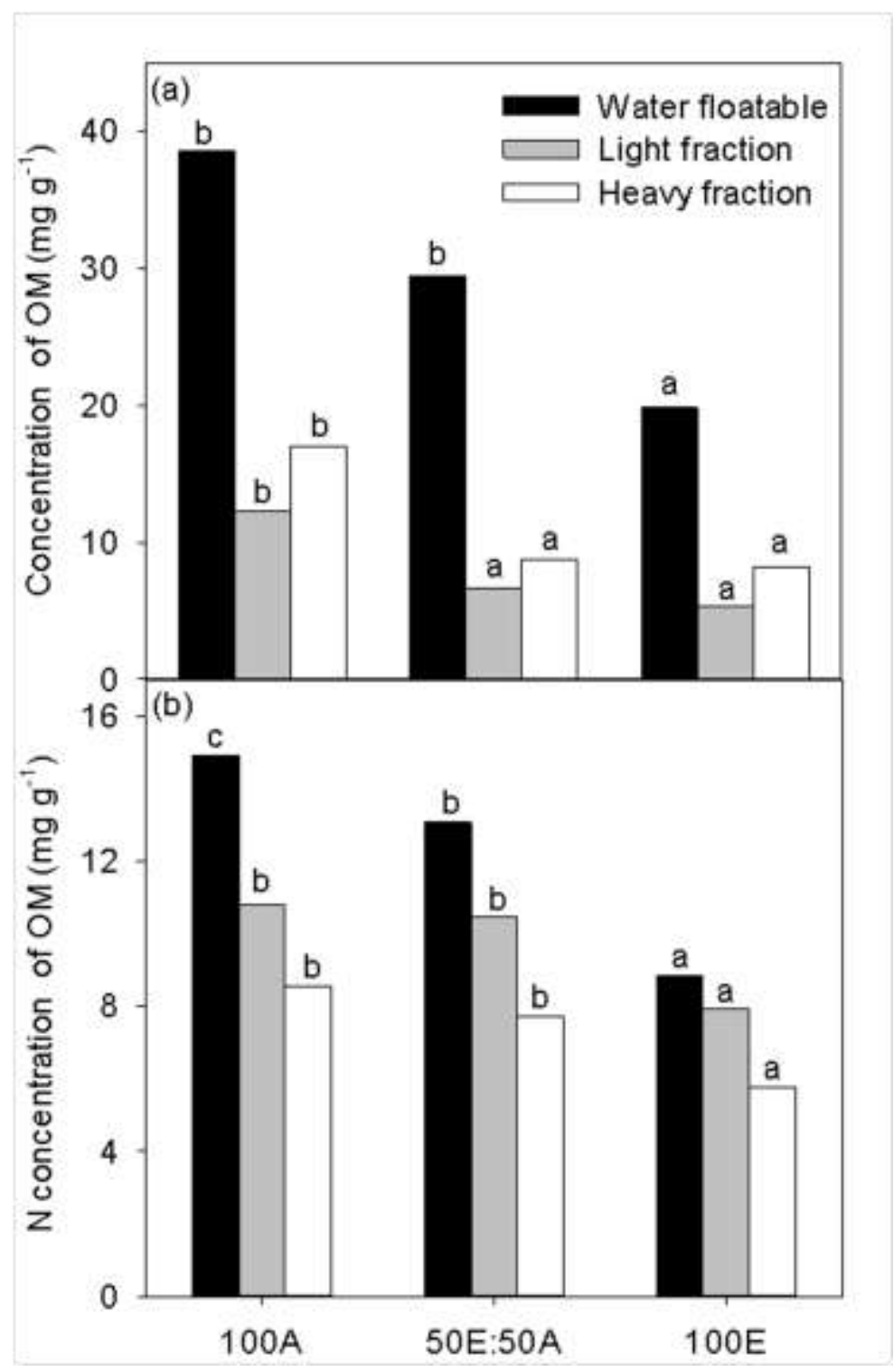




\section{University Library}

\section{- M M N E R VA A gateway to Melbourne's research publications}

Minerva Access is the Institutional Repository of The University of Melbourne

Author/s:

Forrester, DI;Pares, A;O'Hara, C;Khanna, PK;Bauhus, J

Title:

Soil Organic Carbon is Increased in Mixed-Species Plantations of Eucalyptus and NitrogenFixing Acacia

Date:

2013-01-01

Citation:

Forrester, D. I., Pares, A., O'Hara, C., Khanna, P. K. \& Bauhus, J. (2013). Soil Organic Carbon is Increased in Mixed-Species Plantations of Eucalyptus and Nitrogen-Fixing Acacia. ECOSYSTEMS, 16 (1), pp.123-132. https://doi.org/10.1007/s10021-012-9600-9.

Persistent Link:

http://hdl.handle.net/11343/282700 